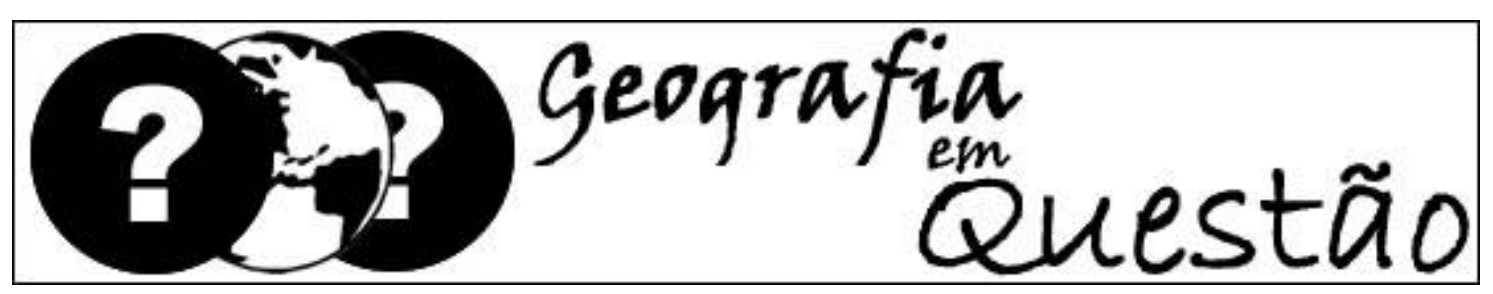

\title{
NORMAS PARA PUBLICAÇÃO
}

Os textos deverão seguir as seguintes normas:

1 - Deverão ser diagramados em fonte Times New Roman 12; Alinhamento Justificado e espaçamento simples; Tamanho do papel A4; margens de $2,5 \mathrm{~cm}$, medianiz de $0 \mathrm{~cm}$; cabeçalhos e rodapés de $1,25 \mathrm{~cm}$ e alinhamento vertical superior. Os parágrafos deverão possuir na primeira linha recuo esquerdo de $1,25 \mathrm{~cm}$. Os subtítulos deverão estar justificados, sem recuo para parágrafo, com a primeira letra em maiúscula e com espaçamento de duas linhas antes e uma depois do texto.

2 - O título deverá ser escrito em fonte Times New Roman 12, em negrito, em letra maiúscula, centralizado e espaçamento simples. Acompanhado de nota de rodapé, indicando o nível da pesquisa, financiamento. Evitar qualquer menção ao nome do autor e/ou orientador, essas informações devem ser inseridas em METADADOS;

3 - O artigo deve ter no máximo quatro autores. O nome do(s) autor(es) NÃO deve constar no artigo. A identificação do(s) autor(es) deve ser feita quando o autor submeter o artigo, através do preenchimento do passo 2 - metadados da submissão (indexação). Informações, como titulação do autor, vínculo etc., devem ser colocadas também no passo 2, em resumo da biografia.

4 - Nos artigos não devem ser feitas referências ao nome do autor mesmo em organização de tabelas, mapas, gráficos, autoria de imagens, etc. Sempre que estas informações forem necessárias deve-se indicar da seguinte forma (ex. onde constar Org. SOUZA, substituir por, Org. AUTOR).

5 - As citações diretas que ultrapassarem 3 linhas deverão possuir fonte 11, serem colocadas em espaçamento simples e recuo esquerdo de $4 \mathrm{~cm}$. Não deverão possuir recuo para parágrafo e deverão estar separadas do texto pelo espaço de uma linha, antes e uma linha depois da citação.

6 - Os textos deverão conter entre 10 laudas (mínimo) e 30 laudas (máximo) para os artigos. E de 03 a 05 laudas para resenhas de livros e notas de pesquisa.

7 - Os artigos deverão incorporar título, resumo e palavras-chave em português e outro idioma. O resumo deve conter até 200 palavras, estar em espaçamento simples, justificado e fonte Times New Roman 11. No caso de artigos em outro idioma que não o português, o resumo e as palavras-chave deverão ser no idioma utilizado no artigo e em português. 


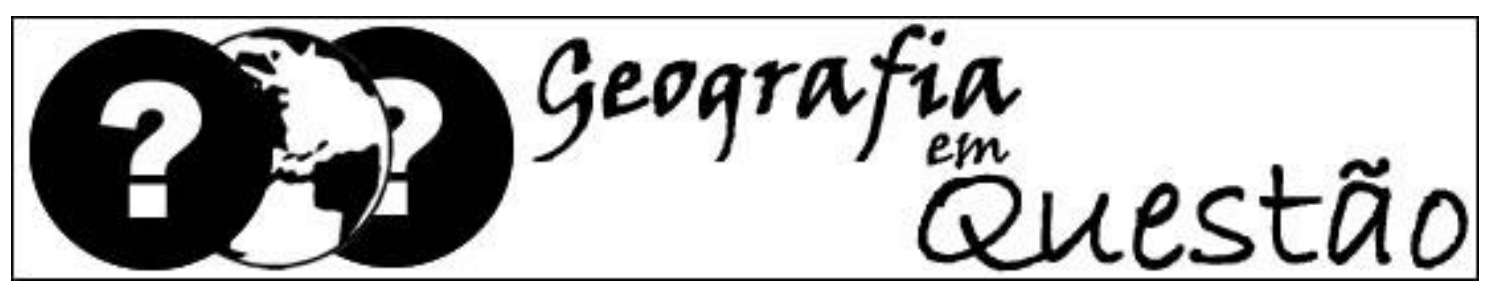

8 - Ilustrações, gráficos, figuras, fotografias, mapas, quadros, tabelas, etc., deverão limitar- se ao espaço de diagramação da revista e ser de boa qualidade gráfica. Seus títulos devem ter apenas a $1^{\mathrm{a}}$ letra de cada palavra em Maiúscula.

9 - O texto deve ser enviado em arquivo doc ou docx.

10 - A bibliografia deve ser apresentada no final do trabalho, em ordem alfabética de sobrenome do(s) autor(es), como nos seguintes exemplos.

a) Livro: SOBRENOME, Nome. Título da Obra. Local de Publicação: Editora, data. Ex.: VALVERDE, Orlando. Estudos de Geografia Agrária Brasileira. Petrópolis: editora Vozes, 1985.

b) Capítulo de Livro: SOBRENOME, Nome. Título do Capítulo. In: SOBRENOME, Nome (Org.). Título do Livro. Local de Publicação: Editora, data, página inicial-página final. Ex.: FRANK, Mônica Weber. Análise Geográfica para Implantação do Parque Municipal de Niterói, Canoas - RS. In: SUERTEGARAY, Dirce. BASSO, Luís. VERDUM, Roberto (Org.). Ambiente e Lugar no Urbano: A Grande Porto Alegre. Porto alegre: Editora da Universidade, 2000, p.67-93.

c) Artigos: SOBRENOME, Nome. Título do Artigo. Título do Periódico, local de publicação, volume do periódico, número do fascículo, página inicial-página final, mês (es). Ano. Ex.: SEABRA, Manoel F. G. Geografia(s)? Orientação, São Paulo, n.5, p.9-17, out.1984.

d) Dissertações e Teses: SOBRENOME, Nome. Título da Dissertação (tese). Local: Instituição em que foi defendida, data. Número de Páginas. (Categoria, Grau e área de Concentração). Ex.: SILVA, José Borzacchiello da. Movimentos Sociais Populares em Fortaleza: Uma Abordagem Geográfica. São Paulo: Faculdade de Filosofia, Letras e Ciências Humanas da Universidade de São Paulo, 1986. 268 p. (Tese, doutorado em Ciências: Geografia Humana).

11 - Os textos devem representar trabalhos originais e inéditos, com introdução, desenvolvimento e considerações finais. As resenhas serão priorizadas a partir de obras publicadas recentemente no Brasil e no exterior.

12 - O autor deve se responsabilizar pela correção (profissional) ortográfica e gramatical do seu artigo.

13 - O resumo em outra língua deve obrigatoriamente passar pela revisão de um profissional, de responsabilidade do autor.

14- A comissão editorial se reserva no direito de arquivar os textos que não atenderem as normas acima. 


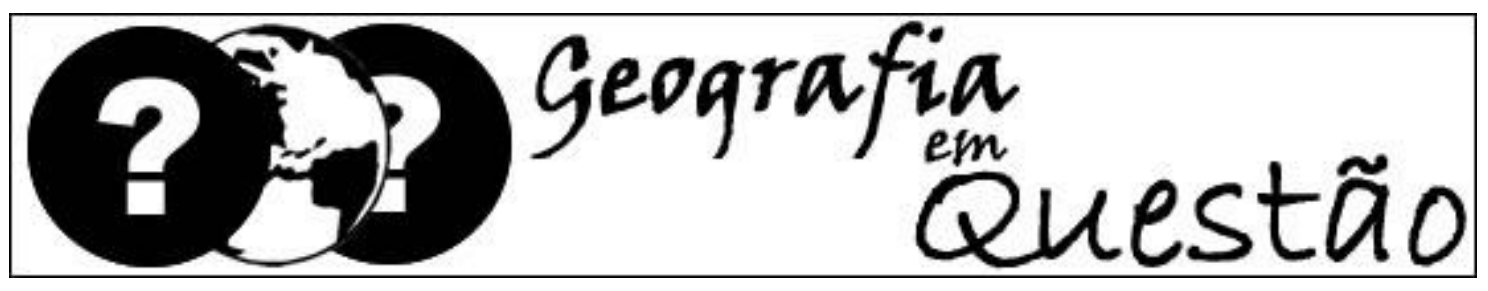

15 - Os textos devem ser enviados para Revista Geografia em Questão. http://erevista.unioeste.br/index.php/geoemquestao

16 - Para maiores esclarecimentos email - geografia.questao@gmail.com

Att. Comissão Editorial 